\title{
Serological and Molecular detection of Staphylococcus aureus isolated from UTI patients
}

\author{
https://doi.org/10.32792/utq/utj/vol14/4/5
}

\section{Ahmed A. R. Abbas* Saad S. Hamim* \\ hamim_pa@sci.utq.edu.iq \\ *Ministry of health-Thi-Qar health office. \\ *Department of pathological analysis-College of science- \\ Thi-Qar University.}

\section{Abstract}

Urinary tract infections (UTIs) are one of the commonest infections encountered by clinicians despite the widespread availability of antimicrobial agents. Such Infections caused by different bacterial pathogens that can be acquired through both hospitals and the community. The present study is aimed to isolation and diagnosis of Staph. aureus, detecting the optimal antimicrobial for the treatment of these infections. A total of (600) mid-stream urine samples were collected during the period from August to December, 2018 from patients who were complained from UTIs at AL-Hussain Teaching Hospital in ALNasiriyah City, Southern Iraq. The study included isolation and diagnosis of Staph. aureus based on morphological, microscopic characterization, biochemical tests and confirmed by API-20 and Vitek2 systems. In addition, all Staph. aureus isolates were subjected to the serological diagnosis of protein A by using a latex agglutination test and convention PCR technique was used to detect the presence of the 16S rRNA gene (353bp). $380(63.33 \%)$ were positive isolates for bacteriological examination, the Staph. aureus was identified with 50 samples (13.5\%). In addition, all Staph. aureus isolates were assayed for antimicrobial susceptibility against 14 selected antibiotic discs by using the disc diffusion method. All isolates were completely resistant to Penicillin (P), Oxacillin (Ox), and Ampicillin (Amp). While the most effective antibiotics were Nitrofurantoin, Gentamycin, isolates were susceptible to these antibiotics in $76 \%$, and $60 \%$, respectively. Also, In the analysis of the nucleotides sequence of the partial 16S rRNA gene, the results were 
showed that these bacteria actually related to Staph. aureus , according to current result, three of these isolates registered globally in the NCBI Gen bank, and the accession numbers of these isolates are (MK910079.1),( MK910080.1), and (MK910081.1).

Keywords: Staphylococcus aureus, Urinary tract infections, Identification, Serological and Molecular diagnosis

\section{Introduction}

Urinary tract infections (UTIs) are infections caused by the presence and growth of microorganisms anywhere in the urinary tract and may be the single most common human bacterial infections [1]. The urinary tract includes the organs that collect, store and release urine from the body, including kidneys, ureters, bladder, and urethra. UTIs are among the most common human bacterial infections in the community or hospital settings and has been reported in both sexes in all age groups [2]. The prevalence and incidence of UTI in women are higher than in men, which is probably the result of several clinical factors, including anatomical differences, hormonal effects and behavioral patterns [3]. About 150 million people worldwide develop UTI each year, with high social costs [4]. UTI accounts for a large portion of the workload in clinical microbiology laboratories and enteric bacteria (Escherichia coli in particular) remain the most common cause of UTI, although the distribution of UTI allowing pathogens is changing [5]. Some other pathogens are associated with UTIs like Staphylococcus, Staph. aureus which is a major human pathogen and a widespread contaminant in hospitals. Although Staph. aureus isolation from urine samples is often secondary to Staphylococcal bacteremia that occurs elsewhere (e.g. endocarditis cases), In some patients, Staph. aureus causes colonization and infection in the urinary tract. Instrumentation of the urinary tract and presence of an indwelling catheter increase the risk of Staph. aureus carriage of the urinary tract. Majority of cases Staph. aureus bacteriuria is not associated with symptoms of urinary tract infection because bacteriuria nearly universally occurs concomitantly with long-term urinary catheterization [6]. The susceptibility of Staph. aureus to the penetration of the body's defenses and tissue invasion and possession of virulence factors such as toxin and 
enzyme production, including high antibiotic resistance [7]. In the past few decades, Staph. aureus is considered as one of the most common nosocomial infections due to various virulence factors, acquisition of antibiotic resistance genes, poor sanitation, and hygiene of health care setting and discriminate use of antibiotics [8]. Also, Staph. aureus has a number of identifying properties, including free coagulase, clumping factor (bound coagulase), thermonuclease, and protein A [9]. The present study aimed to investigate the molecular characterization of 16S RNA gene in Staph. aureus isolates from UTI patients.

\section{Materials and Methods}

\subsection{Samples collection}

Samples were collected from 600 UTI patients from both sexes with different ages, based on the symptoms and which diagnosed by physician and microscopic examination of urine, Patients had taken care and medications in AL- Hussein Teaching Hospital in AL- Nassiriyah City South of Iraq, during the period from August to December, 2018.

\subsection{Isolation, Identification \& biochemical tests of Staph. aureus}

Collected specimens were inoculated on several types from culture media which included blood agar, mannitol salt agar, and Staph 110 agar base according to standard methods. Staph. aureus was identified depending on the morphological features of culture media. Isolates were stained by Gram stain to detect their response to stain, shapes and their arrangement[10]. The biochemical tests used include Catalase, Coagulase, Oxidase and Novobiocin [11].The bacterial diagnosis was confirmed by API system and Vitek2 compact (BioMerieux, France).

\subsection{Antibiotic susceptibility test for Staph. aureus isolates}

All Staph. aureus isolates were subjected to antibiotic susceptibility by using disc diffusion method [12]. The inhibition zone diameters were measured and interpreted according to [13].

\subsection{Serological diagnosis}

All isolates were subjected to a serological diagnosis of protein A by using a latex agglutination test. This test consists of yellow latex particles that have been coated with fibrinogen and rabbit immunoglobulin $\mathrm{G}$ (IgG) specific for Staph. aureus. This test was performed according to the directions of the manufacturing company (Remel, UK). 



\subsection{Molecular detection}

1. DNA extraction and purification: DNA was extracted and purified according to the company manufacturer instructions (Geneaid / Korea).

2. Staph. aureus isolates were subjected to the detection of the $16 \mathrm{~S}$ rRNA gene by conventional PCR technique using specific primer pairs (Table 1). The amplification was conducted in a thermal cycler (BioRad / USA ) which has been programmed with the following conditions: an initial denaturation step for $5 \mathrm{~min}$. at $95^{\circ} \mathrm{C}$ with one cycle, 30 cycles of amplification were performed as follows: denaturation at $95^{\circ} \mathrm{C}$ for $30 \mathrm{sec}$ annealing at $58^{\circ} \mathrm{C}$ for $30 \mathrm{sec}$ and extension at $72^{\circ} \mathrm{C}$ for $1 \mathrm{~min}$ followed by a final extension step at $72^{\circ} \mathrm{C}$ for $5 \mathrm{~min}$. These conditions were designed by the researcher in this study.

3. DNA sequencing: Three PCR products of the 16S rRNA gene were selected for the sequencer. The sequencing of gene reverse and forward primers was done in Macrogen, Korea outside of Iraq. Basic Local Alignment Search Tool analysis (BLAST) was lead to a blast algorithm. The sample sequences designated as (No1, No2 and No3) were edited, aligned and compared with the reference sequences by using Unweighted Pair Group Method with Arithmetic Mean (UPGMA tree) with MEGA6 software. Thus, the MEGA version 6.0 was used to construct phylogenetic tree.

The PCR primers were designed online and provided by (Macrogen, Korea) using NCBI Gene Bank and primers 3 plus [14] as follows (Table1).

Table 1 : Primer sequences of 16S rRNA gene in Staph. aureus .

\begin{tabular}{|c|c|c|c|}
\hline Gene & \multicolumn{2}{|c|}{ Primer Sequences (5'-3') } & $\begin{array}{c}\text { Product size } \\
\text { (bp) }\end{array}$ \\
\hline $\begin{array}{c}\text { 16S rRNA } \\
\text { Staph. } \\
\text { aureus }\end{array}$ & $\mathrm{F}^{*}$ & GTTGACTGCCGGTGACAAAC & \multirow{2}{*}{353} \\
\cline { 2 - 3 } & GCTGTTACGACTTCACCCCA & \\
\hline
\end{tabular}

F: forwared, *R: reverse, T: thymine, C: cytosine, G: guanine, A: adenine 


\section{Results}

\subsection{Isolation of Staph. aureus}

From a total of 600 urine samples from both sexes who suffered from UTI infections with different ages. During the period from August to December, 2018, were collected and tested. The results of the present study showed that $380(63.5 \%)$ isolates noted positive growth of pathogen collected from UTI patients while 220 samples (36.5\%) showed no significant growth. Only (50) samples were given growth Staph. aureus with $13.5 \%$ while $50 \%$ were other types of bacteria and $36.5 \%$ did not grow, as in figure (1).

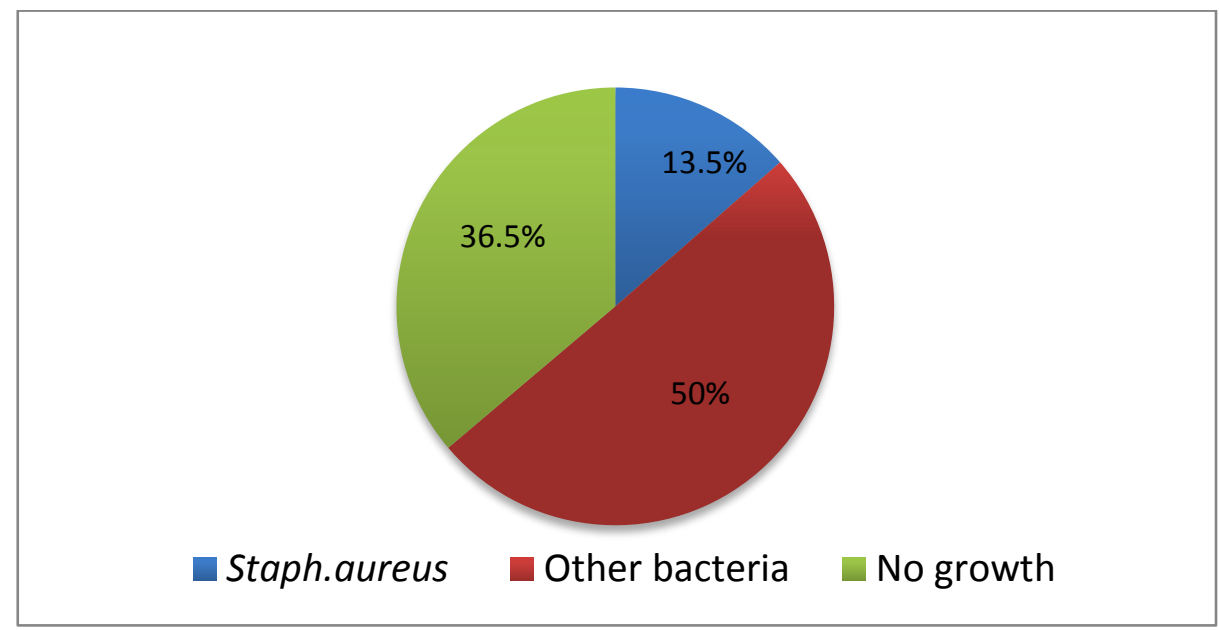

Figure (1): The percentage of Staph. aureus and other bacteria isolated from 600 UTI patients.

\subsection{Macroscopic \& Microscopic examination}

Morphology characteristics of Staph. aureus grow on different media, such as Blood agar, Mannitol salt agar and Staph 110 meduim, then microscopic examination was applied to all 50 isolates after being stained by gram stain to detect their reaction. The cells appeared as gram-positive cocci, mostly arranged in grapes like irregular clusters.

\subsection{Conventional Biochemical tests \& Api-20 system identification}

In the initial stage of identification, all isolates were identified by biochemical tests such as Catalase, Coagulase, Oxidase and Novobiocin. All these tests positive for Staph. aureus. Then, used the API 20 Staph to 
confirm the diagnosis of isolates from Staph. aureus and to complete important biochemical tests. The result of API-20 Staph test has reveals that only 50 isolates identified as Staph. aureus.

\subsection{Serological diagnosis}

All of Staph. aureus isolates were diagnosed by Staphaurex Plus which is a rapid latex agglutination test for the identification of Staphylococci which possess clumping factor, protein A and surface antigens characteristic of Staph. aureus. When a drop of the reagent is mixed on a card with Staph. aureus organisms, rapid agglutination occurs, indicates a positive result. As illustrated in figure (3).

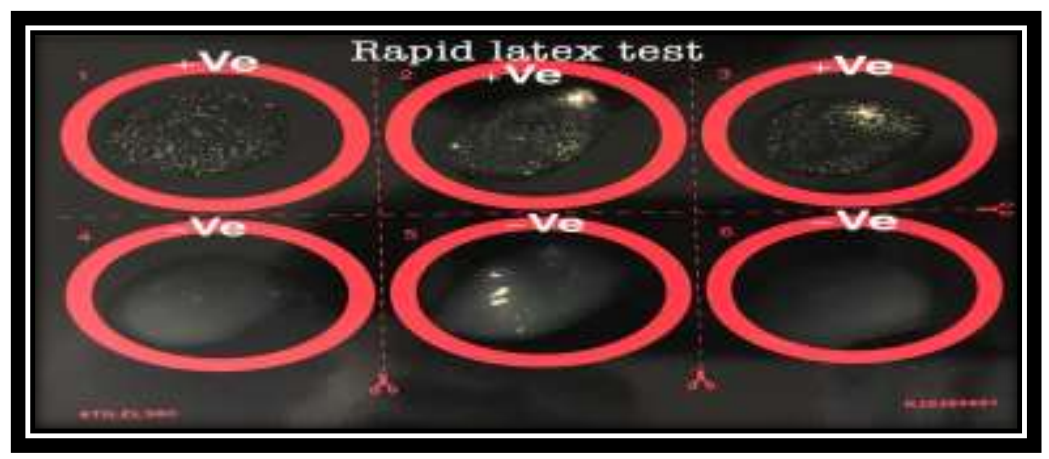

Figure (3): Latex agglutination test for Staph. aureus

\subsection{Antibiotic susceptibility profile of Staph. aureus}

All Staph. aureus $(\mathrm{n}=50)$ was assayed for antibiotic susceptibility test against 14 type of antibiotics. The results showed that there was a variation in resistance rates of the tested bacteria. All Staph. aureus isolates were completely resistant to penicillin $(\mathrm{P})$, Oxacillin $(\mathrm{Ox})$, and Ampicillin (Amp) with (100\%) for the three antibiotics and highly resistant to Trimethoprim-Sulfamethoxazole, Tetracycline (TE) and Rifampicin (RA) with a percentages of (75.0\%),(62.0\%), and (52.0\%), respectively. While the most effective antibiotics for Staph. aureus were Nitrofurantoin, Gentamycin where isolates were susceptible to these antibiotics in $76 \%$, and $60 \%$, respectively. As shown in figure (2). 


\subsection{Molecular diagnosis of Staphylococcus aureus by 16S rRNA}

Fifty isolates of Staph. aureus which were identified by biochemical test, API 20, Vitek 2 system and serological diagnosis were subjected to DNA extraction, PCR assay for sequencing of 16S rRNA gene approximately size (353bp). All the isolates were positive for that gene (100\%), as in figure (4). The DNA sequences and phylogenetic tree analysis are accurate and highly sensitive diagnostic methods and can be used in many aspects of life and practice.

Figure (2): The percentage of antimicrobial susceptibility of Staph.

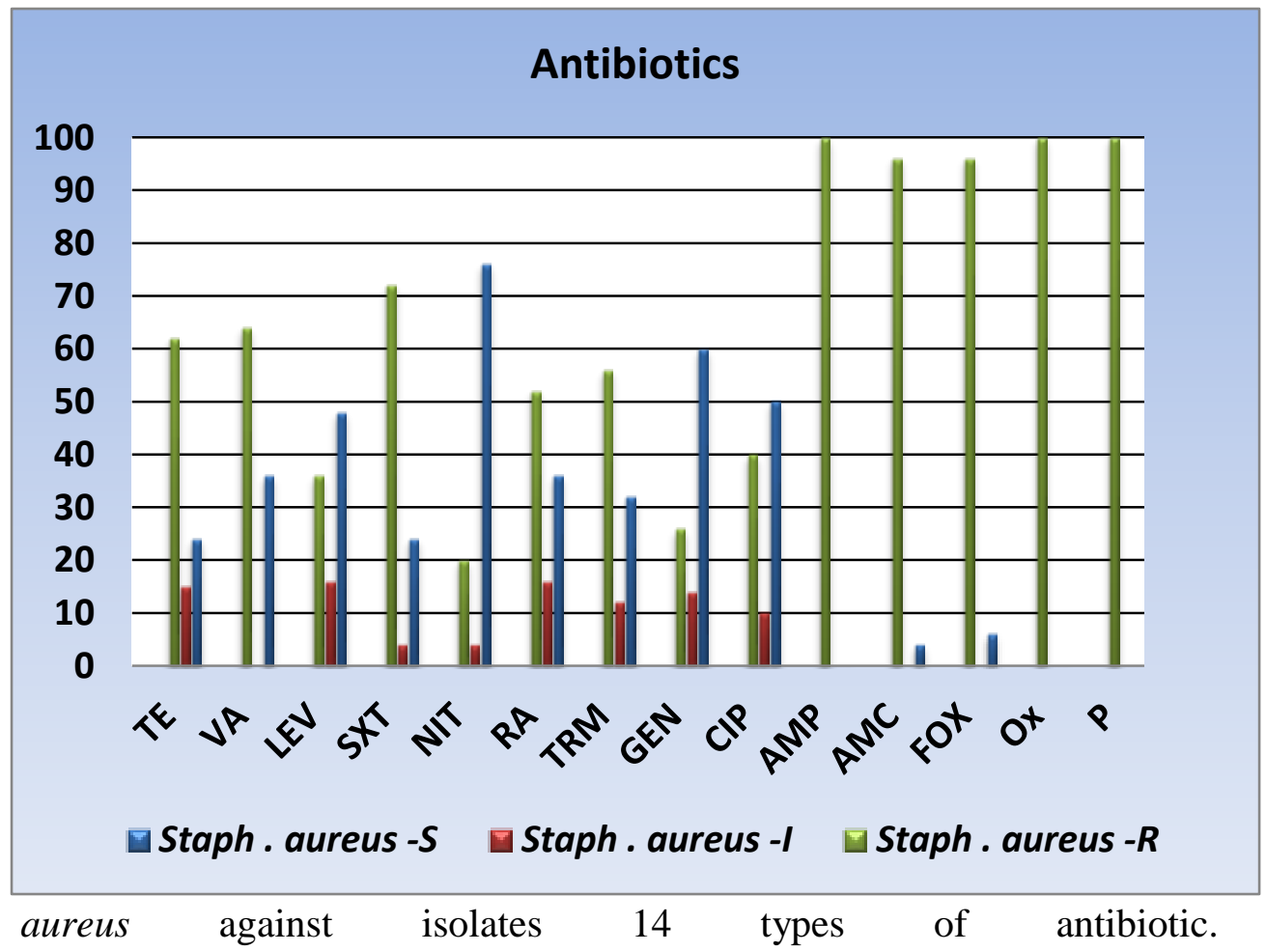




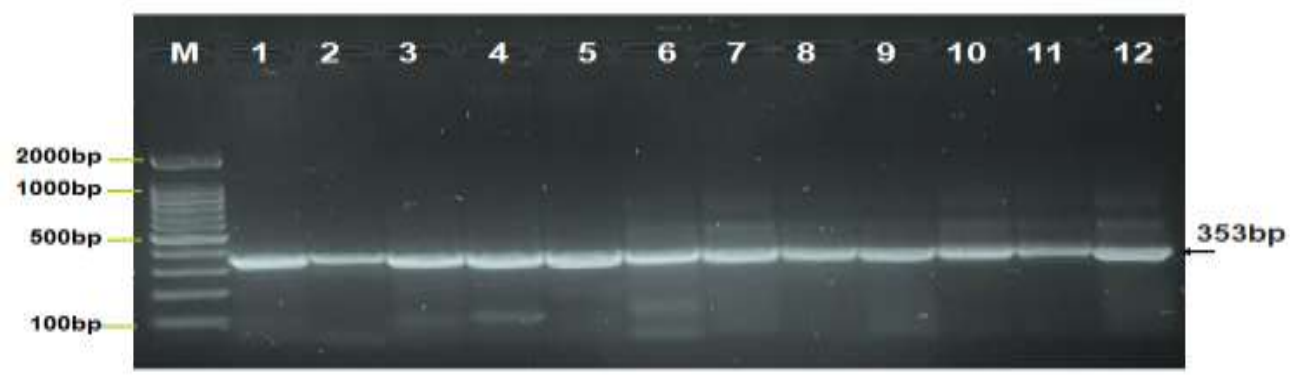

Figure (4): A garose gel electrophoresis presented the analysis of PCR product in Staph. aureus $16 \mathrm{~S}$ ribosomal RNA gene. M represents the Marker ladder with (100-2000bp) while lane (1-12) showed positive Staph. aureus isolates at approximately (353bp) product size.

Figure (5): Phylogenetic tree analysis based on 16 ribosomal RNA gene

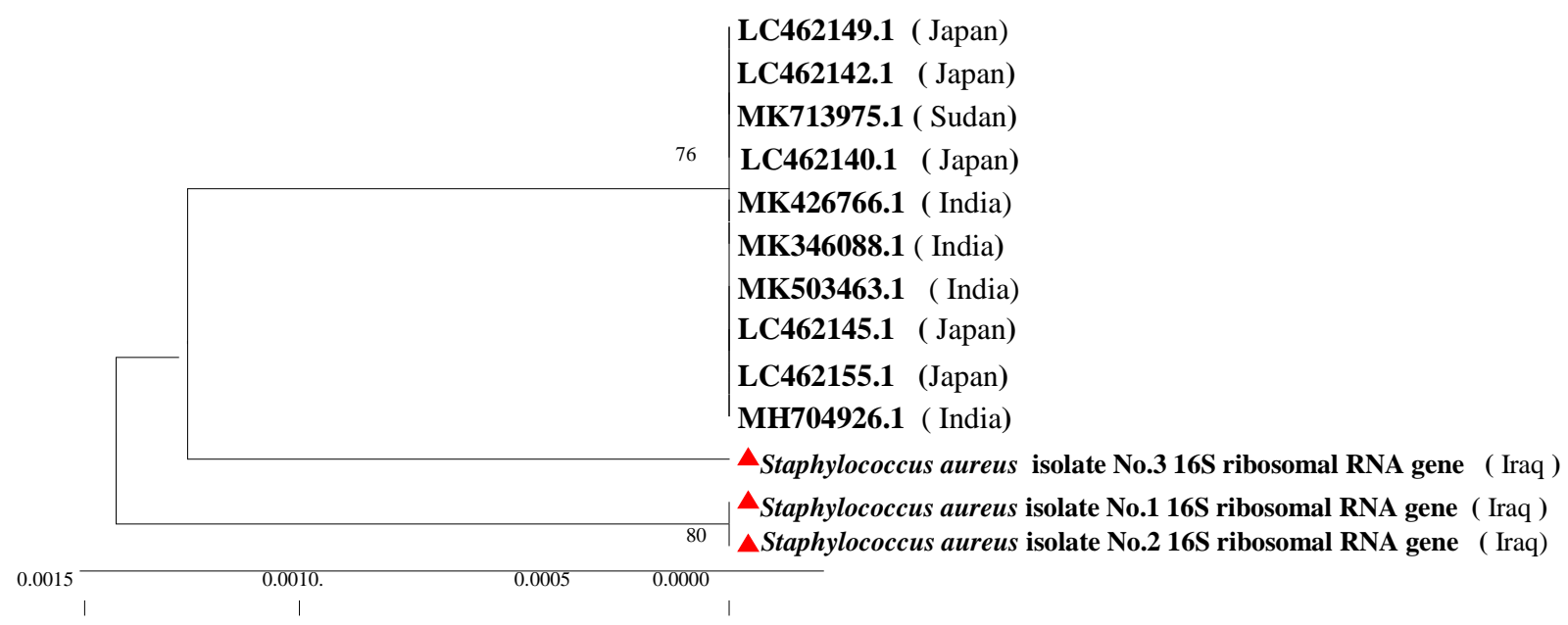

partial sequence in local Staph. aureus human urine isolates that used for genetic Staph. aureus genetic analysis. The phylogenetic tree was constructed using the Unweighted Pair Group Method with Arithmetic Mean (UPGMA tree) in (MEGA version 6.0). 


\section{Discussion}

\subsection{Isolation of Staph. aureus}

Problems in managing urinary tract infections are attributed to factors related to the host and those related to the causative agents of urinary tract infections. UTIs can occur due to the pathogenicity of the organism, susceptibility of the host, or a combination of both factors[15]. The results of the present study showed that Staph. aureus was the most predominant gram-positive species isolated from all UTI cases with a total number of $50 / 380(13.15 \%)$. Inside Iraq, the current results agreed with $[16,17]$ who recorded both of them (11\%) and [18] whom recorded (14.29\%) for Staph. aureus. Outside Iraq, the present results agreed with results of study [19] who document that (13.71\%), of isolates identified as Staph. aureus that isolated from UTI patients. On the other hand, the results of the present study were incompatible with [20,21] where Staph. aureus accounted for only $0.5 \%$, and $1.5 \%$ of isolates respectively, also the results of this study are disagree to other studies, like the results of [22,23], that described a Staph. aureus incidence in UTI with a percentages of $28.9 \%$, and $33.3 \%$, respectively. Prior studies suggest that isolation of Staph. aureus from the urine is often secondary to Staphylococcal bacteremia originating at another site (e.g., in cases of endocarditis) [24]. This is probably due to the fact that Staph. aureus is a member of the normal flora of both asymptomatic carriers and sick persons thus takes advantage of the weak immune system. This organism can be spread by the hands, expelled from the respiratory tract or transmitted by animate or inanimate objects [25].

\subsection{Antibiotic susceptibility of Staph. aureus}

Antimicrobial resistance represents a serious problem in the treatment of infectious diseases including UTI. Antibiotics are the main treatment for all UTIs. A variety of antibiotics are available, and choices depend on many factors, including whether the infection is complicated or uncomplicated or primary or recurrent [26]. Where worldwide data show that there is increasing resistance among urinary tract pathogens to conventional drugs. Antibiotic resistance by Staphylococci is on the increase [27]. The results of antibiotics susceptibility test for Staph. aureus isolates showed that there were a high rate of resistance to most 
of Penicillin drugs. Inside Iraq, the result of the current study seems to be in agreement with [16,28], who recorded that the same resistance to this antibiotics. Outside Iraq, the results of the present study were compatible with[29], whom recorded high a resistance rate to Oxacillin (100\%), Amoxicillin (91.7\%), followed by Penicillin (83.3\%). Penicillin resistance may be due to the structural modification of enzymatic action ( $\beta$-lactame action) or the prevention of access to target by altering the outer membrane permeability and may be due to the alternation of the antibiotic target site and sometimes the resistance is due to efflux pump which pumps out the antibiotic [30]. Staph. aureus develops resistance very quickly and successfully to different antimicrobials over some time. The present study showed that Staph. aureus isolates were highly susceptible to Nitrofurantoin and Gentamycin, a finding that was consistent to that reported by $[31,32]$ where they recorded a sensitive rate of $(79.5 \%, 52.3 \%)$, and $(85 \%, 80 \%)$, respectively. On the other hand, these results were incompatible with similar studies performed by [33] who founded completely sensitivity of Staphylococcus spp. to gentamycin with a percentage of $(100 \%)$. Also, do not agree with the [18] where the isolates were $(75.6 \%)$ resistant to gentamycin.

\subsection{Serological diagnosis}

Protein A was tested for all isolates of Staph. aureus under study. The method used in this research is easy to apply as well as sensitive. Staph. aureus isolates showed significant variation in their containment of protein A associated with the cell wall. Some isolates of Staph. aureus were found to possess this protein. It is the result of having high protein A content that is part of its wall, but the lack of possession of some isolates of Staph. aureus of this protein these are due to many reasons, the most important reasons, where the type of culture medium and its components is of great importance in the production of protein A. Research on the effect of carbon source in the production of protein A indicates that the presence of mannitol in the culture medium leads to inhibition of protein production. The presence of high concentration salt affects the production of protein A inhibits its production and affects the correlation efficiency between protein A and the fraction of FC of IgG [34]. 


\subsection{Molecular detection of Staph. aureus}

Using of Polymerase Chain Reaction (PCR) technique increases the accuracy and speed of Staph. aureus identification and validation [35]. The DNA sequences and phylogenetic tree analysis are accurate and highly sensitive diagnostic methods and can be used in many aspects of life and practice [36]. All isolates gave a positive reaction to the $16 \mathrm{~S}$ rRNA gene. This finding agrees with other local studies $[37,38,39]$ who revealed the complete percentage of the 16SrRNA gene. Outside Iraq, some results agreed to go for from what was recorded [40,41] who recorded that all isolates had $16 \mathrm{~S}$ rRNA. Also, the results of this study disagree with[42]. These differences may be due to many factors; such as the sources and number of the clinical samples used, geographical dependency, and the sensitivity of different techniques used. This gene was used for diagnosis and through this tree we found that the isolates of the study were genetically identical by $99 \%$ with those found in the genebank. The isolates of the three studies are genetically far from the genes taken from the genebank because they appeared in the out group, especially isolates No.1 and No.2 that appeared genetically identical while isolate No. 3 has a genetic relationship with the genes taken from the genebank this is confirmed by the value of the boot strap, which amounted to $76 \%$. The value of the boot strap that appeared among the study isolates was good. The constructed phylogenetic tree showed that Staph. aureus MK910079.1 and MK910080.1 were highly relative to each other in comparison with Staph. aureus MK910081.1 that revealed a close relatedness to Staph. aureus from India, Sudan and Japan, at total genetic changes $(0.0005-0.0015 \%)$ (Fig. 5).

\section{Conclusions}

Staphylococcus aureus consider as one of important Gram positive causative agents of UTI infections and has become one of the most successful adaptable human pathogens.

\section{References:}

[1] Negussie, A.; Worku, G., and Beyene, E. (2018). Bacterial identification and drug susceptibility pattern of urinary tract infection in pregnant women

at

Karamar Hospital Jigjiga, Eastern Ethiopia. African Journal of Bacteriology Research, 10(2): 15-22.

[2] Hassan, H. E. M.; Altayb, H. N.; El Hassan, M. M., and Elmekki, M. A. (2018). Genotypic detection of the virulence factors of uropathogenic Escherichia coli isolated from diarrheic and urinary tract infected patients in 
Khartoumn State, Sudan.African Journal of Microbiology Research,12(9): 230236.

[3] Griebling, T. L. (2018). How Often do Clinically Diagnosed CatheterAssociated Urinary Tract Infections in Nursing Homes Meet Standardized Criteria?. The Journal of urology, 200(6): 1141-1144.

[4] Flores-Mireles, A. L., Walker, J. N., Caparon, M., and Hultgren, S. J. (2015). Urinary tract infections: epidemiology, mechanisms of infection and treatment options. Nature reviews microbiology, 13(5): 269.284.

[5] Bradley, C. W.; Flavell, H.; Raybould, L.; McCoy, H.; Dempster, L.; Holden, E., and Garvey, M. I. (2018). Reducing Escherichia coli bacteraemia associated with catheter-associated urinary tract infections in the secondary care setting. Journal of Hospital Infection, 98(3): 236-237.

[6] Muder, R. R.; Brennen, C.; Rihs, J. D.; Wagener, M. M.; Obman, A.; Obman, A., and Yu, V. L. (2006). Isolation of Staphylococcus aureus from the urinary tract: association of isolation with symptomatic urinary tract infection and subsequent Staphylococcal bacteremia. Clinical infectious diseases, 42(1): 46-50.

[7] Brooks, G. F.; Carroll, K. C.; Butel, J. S.; Morse, S. A., and Mietzner, T.A(2013). Medical Microbiology, (26 ${ }^{\text {th }}$ ed.). New York. USA: McGraw-Hill Education, p.880.

[8] Kumosani, T. (2014). Nosocomial Infections in Saudi Arabia Caused by Methicillin Resistance Staphylococcus aureus (MRSA). Clinical Microbiology: Open Access, 03(03): 2-5.

[9] Smith, D. S.; Siggins, M. K.; Gierula, M.; Pichon, B.; Turner, C. E.; Lynskey, N. N., and Sriskandan, S. (2016). Identification of commonly expressed exoproteins and proteolytic cleavage events by proteomic mining of clinically relevant UK isolates of Staphylococcus aureus. Microbial genomics, 2(2).

[10] Benson, J. H. (2001). Microbiological Applications: Laboratory Manual in General Microbiology. (8th ed). McGraw-Hill Higher Education, New York, PP: 125-130.

[11] MacFaddin, J. F. (2000). Biochemical tests for identification of medical bacteria, (3rd ed.). USA: Lippinocott Williams and Wilkins, p. 912.

[12] Bauer, A. W.; Kirby, W. M. M.; Sherris, J. C., and Turck, M. (1966). Antibiotic susceptibility testing by a standardized single disk method. American journal of clinical pathology, 45(4): 493-496. 
[13] Clinical and Laboratory Standards Institute (2018). Performance standards for antimicrobial susceptibility testing of anaerobic bacteria: informational supplement. CLSI document M100, (28th ed.) Wayne, PA USA.: 258p.

[14] Untergasser, A.; Nijveen, H.; Rao, X.; Bisseling, T.; Geurts, R., and Leunissen, J. A. (2007). Primer3Plus, an enhanced web interface to Primer3. Nucleic acids research, 35(2): W71-74.

[15] Flores-Mireles, A. L.; Walker, J. N.; Caparon, M., and Hultgren, S. J. (2015). Urinary tract infections: epidemiology, mechanisms of infection and treatment options. Nature reviews microbiology, 13(5): 269-284.

[16] Al-Jebouri, M. M., and Mdish, S. A. (2013). Antibiotic resistance pattern of bacteria isolated from patients of urinary tract infections in Iraq. Open Journal of Urology, 3(02): 124-131.

[17] Abdulrahman, I. S. (2018). Antimicrobial Susceptibility Pattern of Pathogenic Bacteria Causing Urinary Tract Infections at Azadi Hospital In Duhok CitylKurdistan Region of Iraq. Science Journal of University of Zakho, 6(2): 46-50.

[18] Alsamarai, A. G. M.; Khorshed, S. A., and Ali, H. (2016). Urinary tract infection in female in Kirkuk, Iraq: impact of younger aged women compared to diabetic and pregnant women. World Journal Of Pharmacy and Pharmaceutical Sciences, 5(11), 73-86.

[19] Mollick, S.; Dasgupta, T.; Hasnain, M. J., and Ahmed, M. (2016). Isolation and characterization of pathogens responsible for urinary tract infection in Bangladesh and determination of their antibiotic susceptibility pattern. Journal of Applied Pharmaceutical Science, 6(04): 072-076.

[20] Barrett, S. P.; Savage, M. A.; Rebec, M. P.; Guyot, A.; Andrews, N., and Shrimpton, S. B. (1999). Antibiotic sensitivity of bacteria associated with community-acquired urinary tract infection in Britain. Journal of Antimicrobial Chemotherapy, 44(3): 359-365.

[21] Mane, M. S.; Sandhya, B. K.; Priya, R .L., and Magdalene, J. (2015). Prevalence and antibiotic susceptibility pattern of bacterial isolates from urinary tract infection in a tertiary care hospital in Tamilnadu. Journal of medical and dental sciences, 14 (7): 59-65.

[22] Okonko, I. O.; Ijandipe, L. A.; Ilusanya, A. O.; Donbraye-Emmanuel, O. B.; Ejembi, J., Udeze, A. O., and Nkang, A. O. (2010). Detection of urinary tract infection (UTI) among pregnant women in Oluyoro Catholic Hospital, Ibadan, South-Western Nigeria. Malaysian journal of Microbiology, 6(1): 16-24.

[23] Alwash, S. J., and Saleh, D. S. (2013). Comparison between Cefoxitin disk diffusion, Crome agar and EPI-M Screening Kit for Detection of MethicillinResistant Staphylococcus aureus. Iraqi Journal of Science, 54(4): 847-850. 
[24] Muder, R. R.; Brennen, C.; Rihs, J. D.; Wagener, M. M.; Obman, A.; Obman, A., and Yu, V. L. (2006). Isolation of Staphylococcus aureus from the urinary tract: association of isolation with symptomatic urinary tract infection and subsequent Staphylococcal bacteremia. Clinical infectious diseases, 42(1): 46-50.

[25] DeLeo, F. R.; Diep, B. A., and Otto, M. (2009). Host defense and pathogenesis in Staphylococcus aureus infections. Infectious disease clinics of North America, 23(1): 17-34.

[26] Zahera, M.; Rastogi, C.; Singh, P.; Iram, S.; Khalid, S., and Kushwaha, A. (2011). Isolation, identification and characterization of Escherichia coli from urine samples and their antibiotic sensitivity pattern. European Journal of Experimental Biology, 1(2): 118-124.

[27] Khan, R. A.; Khan, F. A.; Iqbal, M., and Nigar, H. (2019). Prevalence and antibiotic susceptibility of multi-drug resistant Staphylococcus aureus and Acinetobacter baumannii in clinical samples from intensive care unit patients in a tertiary care hospital at Peshawar (Pakistan). Anaesthesia, Pain and Intensive Care, 231-236.

[28] Hussein, N. R.; Daniel, S.; Salim, K., and Assafi, M. S. (2018). Urinary Tract Infections and Antibiotic Sensitivity Patterns Among Women Referred to Azadi Teaching Hospital, Duhok, Iraq. Avicenna Journal of Clinical Microbiology and Infection, 5(2): 27-30.

[29] Chandrasekaran, D.; Venkatesan, P.; Tirumurugaan, K. G.; Nambi, A. P.; Thirunavukkarasu, P. S.; Kumanan, K., and Ramesh, S. (2014). Pattern of antibiotic resistant mastitis in dairy cows. Veterinary World, 7(6): 389-394.

[30] Chakraborty, S. P.; KarMahapatra, S.; Bal, M., and Roy, S. (2011). Isolation and identification of vancomycin resistant Staphylococcus aureus from postoperative pus sample. Al Ameen Journal of Medical Sciences, 4(2): 152168.

[31] Hammoudi, A. A. (2013). Urinary tract infection of adults in Baghdad City. International Journal of Current Microbiology and Applied Sciences, 2: 1-6.

[32] Sujatha, R., and Pal, N. (2015). Antibiotic Resistance Pattern Of The Hospital And Community Acquire Isolates Of Uropathogens In A Teritiary Care Centre at Kanpur" Rama Univ. Journal of Medical Sciences, 1(1): 10-17.

[33] Bendahou, A.; Lebbadi, M.; Ennanei, L.; Essadqui, F. Z., and Abid, M. (2008). Characterization of Staphylococcus species isolated from raw milk and milk products (lben and jben) in North Morocco. The Journal of Infection in Developing Countries, 2(03): 218-225.

[34] Cheung, A. L.; Nishina, K. A.; Trotonda, M. P., and Tamber, S. (2008). The SarA protein family of Staphylococcus aureus. The international journal of biochemistry and cell biology, 40(3): 355-361. 
[35] Rallapalli, S.; Verghese, S., and Verma, R. S. (2008). Validation of multiplex PCR strategy for simultaneous detection and identification of methicillin resistant Staphylococcus aureus. Indian Journal of Medical Microbiology, 26(4): 361-364.

[36] Didelot, X.; Bowden, R.; Wilson, D. J.; Peto, T. E., and Crook, D. W. (2012). Transforming clinical microbiology with bacterial genome sequencing. Nature Reviews Genetics, 13(9): 601-612.

[37] Ibed, A. N., and Hamim, S. S. (2014). Molecular detection of methicillin resistant Staphylococcus aureus isolated from burns infection in Al-Nasiriyah City. World Journal of Pharmaceutical Sciences, 2: 950-954.

[38] Degaim, Z. D.; Shani, W. S., and Hamim, S. S. (2015). Virulence factors of Methicillin Resistant Staphylococcus aureus (MRSA) isolated from burn patients. International Journal of Current Microbiology and Applied Sciences, 4: 898-906.

[39] Hashim, I. A.; Wdaah, Q. H., and Atya, A. A. (2019). Potential effect of antimicrobial agents against Staphylococcus aureus and Pseudomonas aeruginosa strains from patients with skin infections. University of Thi-Qar Journal of Science, 7(1): 7-14.

[40] Makgotlho, P. E.; Kock, M. M.; Hoosen, A.; Lekalakala, R.; Omar, S.; Dove, M., and Ehlers, M. M. (2009). Molecular identification and genotyping of MRSA isolates. Federation of European Microbiological Societies Immunology and Medical Microbiology, 57(2): 104-115.

[41] Al-Talib, H.; Yean, C. Y.; Al-Khateeb, A.; Hassan, H.; Singh, K. K. B.; AlJashamy, K., and Ravichandran, M. (2009). A pentaplex PCR assay for the rapid detection of methicillin-resistant Staphylococcus aureus and Panton-Valentine Leucocidin. BMC microbiology, 9(1): 113-119.

[42] Zhang, K.; Sparling, J.; Chow, B. L.; Elsayed, S.; Hussain, Z.; Church, D. L., and Conly, J. M. (2004). New quadriplex PCR assay for detection of methicillin and mupirocin resistance and simultaneous discrimination of Staphylococcus aureus from Coagulase-Negative Staphylococci. Journal of clinical microbiology, 42(11), 4947-4955 
الكثف المصلي والجزيئي للمكورات العنقودية الذهبية المعزولة من مرضى المهاب

التهاب المسالك البولية

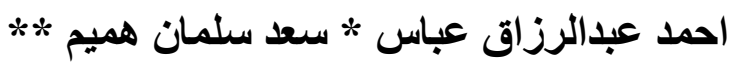

\section{hamim_pa@sci.utq.edu.iq}

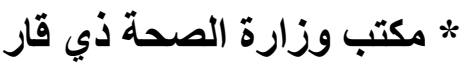

** قسم التحليلات المرضية ، كلية العلوم ، جامعة ذي قار فار ، العراق

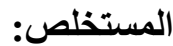

تعثبر التهابات المسالك البولية واحدة من أكثر الإصابات شيو عًا التي يو اجهها الأطباء على الرغم

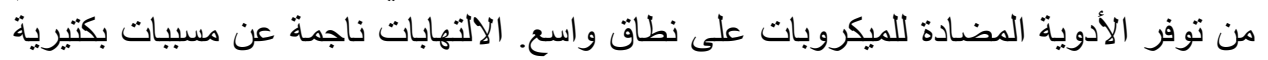

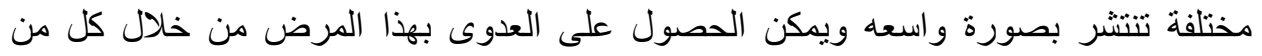

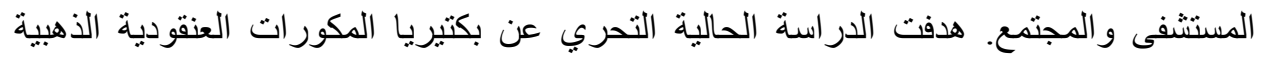

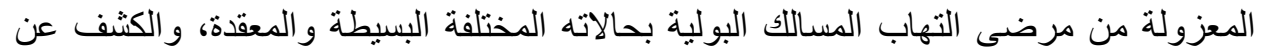

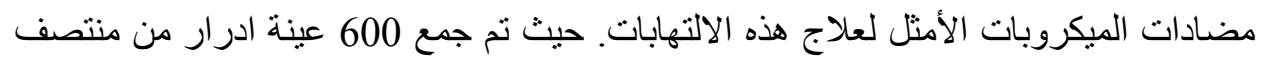

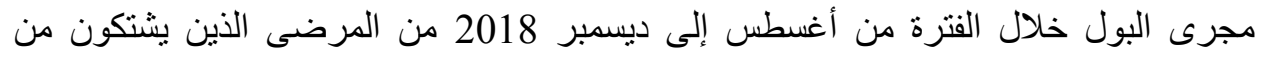

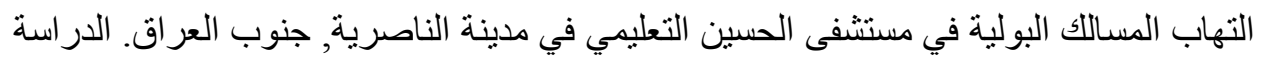

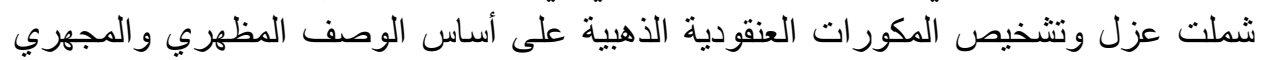

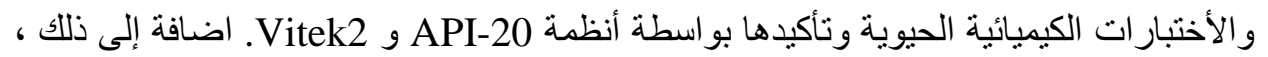

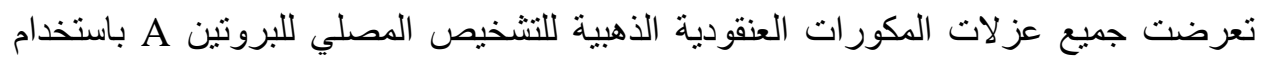

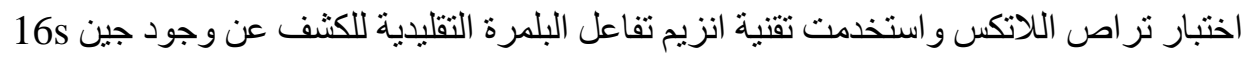

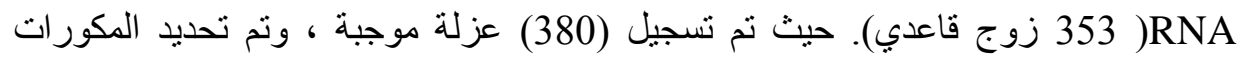

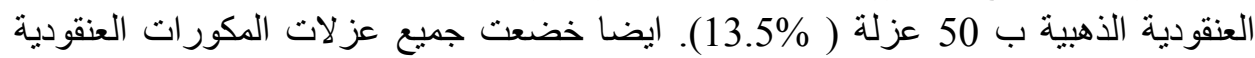

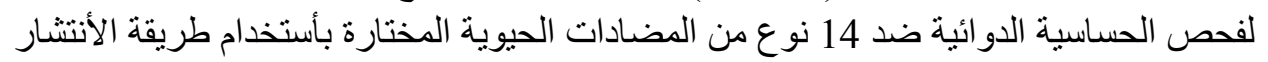

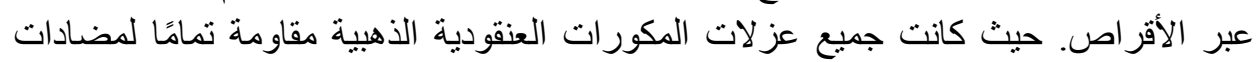

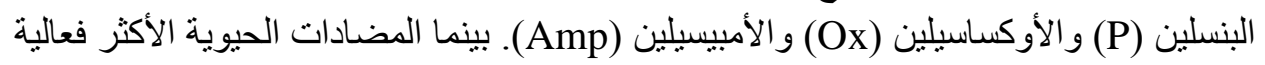

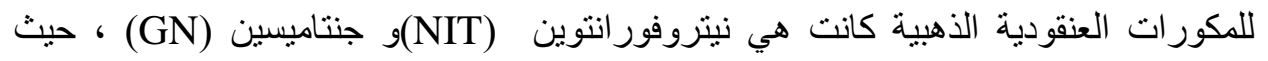

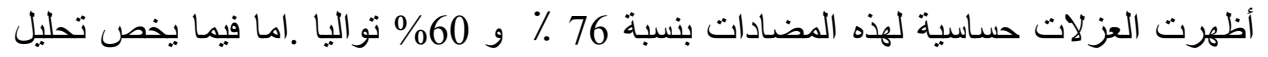

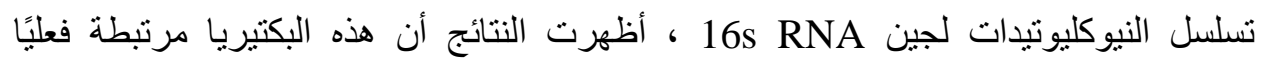

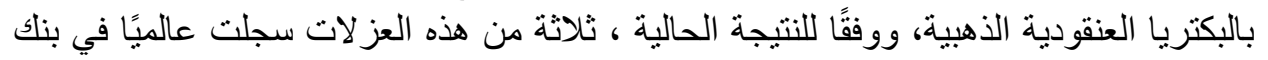

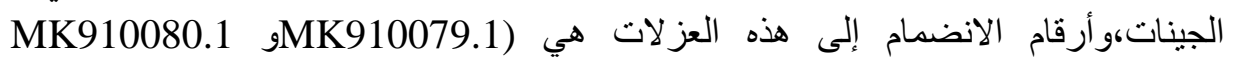

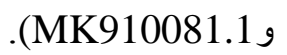

الكلمات المفتاحية: الككورات العنقودية الذهبية ، التهابات المسالك البولية ، التثخيص ، الكثف

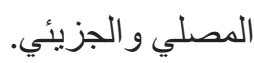

